\title{
Журналістське дослідження в українських реаліях
}

\author{
Вікторія \\ ГАЛУДЗІНА-ГОРОБЕЦЬ \\ канд. мистецтвознавства, доц. \\ Київський національний \\ університет культури і мистецтв \\ вул. Є. Коновальця, 36, \\ Київ, Україна, 01133 \\ torrygal@ukr.net \\ ORCID ID 0000-0002-0757-6665 \\ (c) Галудзіна-Горобець В., 2021
}

У статті розглядається теоретичний аспект особливостей журналістського розслідування в інформаційному просторі.

Теоретико-методологічної базою дослідження стали праці сучасних журналістикознавців (О. Дудко, А. Бабінець, В. Здоровега, О. Тертичний, В. Карпенко, Г. Кривошея та інші). Рецепція наукових праць згаданих дослідників дозволила виокремити специфічні риси аналітичних жанрів, зокрема журналістського розслідування.

У статті підкреслюється, що на шляху становлення журналістського розслідування була так звана «Вотергейтська справа» (від назви вашингтонського готелю «Вотергейт», у якому розмістився штаб Демократичної партії), започаткована кореспондентами газети «The Washington Post». Журналістське розслідування змінило хід історії і відтоді зайняло пріоритетні позиції серед найпрестижніших жанрів незалежних ЗМІ в Америці, а згодом і в європейських країнах. I насамперед унаслідок того, що журналісти у цих державах були захищені існуючим рівнем демократії.

Окреслено, що за період розбудови незалежності з початку 90-х рр. ХХ ст. Україна пережила доволі багато політичних і суспільних скандалів, під час яких десятки чиновників були змушені з ганьбою залишити свої посади. Здебільшого першопричиною для відкриття справ ставали журналістські розслідування. Очевидно, що для деяких кіл, пов'язаних із великою політикою, бізнесом, владою, вторгнення журналістів у ці, здебільшого напівзакриті від широкої громадськості сфери, завжди було небажаним.

Зроблено висновок, що після Революції Гідності журналістське розслідування стає одним із головних жанрів української журналістики. Цей жанр виконує величезну соціальну місію: він спрямований на викриття несправедливості, порушень закону або навіть злочинів, які залишаються поза увагою правоохоронних органів.

Ключові слова: жанр, журналістські розслідування, аналітичні жанри, аналітична журналістика. 


\title{
JOURNALISTIC RESEARCH IN UKRAINIAN REALITIES
}

\author{
Victoriia Haludzina-Horobets \\ PhD in Art History, Associate Professor \\ Kyiv National University of Culture and Arts \\ 36 Ye. Konovaltsia St., Kyiv, Ukraine, 01133 \\ ORCID ID 0000-0002-0757-6665 \\ torrygal@ukr.net
}

The article considers the theoretical aspect of journalistic investigation genre features in the information space.

The theoretical and methodological basis of the study was the works of modern journalists (V. Ivanov and O. Dudko, A. Babinets, G. Kryvosheya, V. Zdoroveha, O. Tertychniy, $V$. Karpenko, and others). The reception of the mentioned researchers scientific works made it possible to distinguish specific features of analytical genres, including journalistic investigations.

The article emphasizes that the so-called "Watergate case" (from the name of the Washington hotel "Watergate", which houses the headquarters of the Democratic Party), founded by the correspondents of The Washington Post, was on the way to the formation of investigative journalism genre. The journalistic investigation changed the course of history and since has taken priority positions among the most prestigious genres of independent media in America and later in European countries. And first of all, because that journalists in these countries were protected by the existing level of democracy.

It is outlined that during the period of independence development from the beginning of the 90s of the 20th century, Ukraine has experienced many political and social scandals, during which dozens of officials were forced to resign in disgrace. Basically, the root cause for the discovery of cases was journalistic investigations. Of course, for certain circles, in particular, those involved in big politics, power, business, the intrusion of journalists into these areas, which are mostly semi-closed to the general public, has always been undesirable.

It is concluded that after the Revolution of Dignity, investigative journalism became one of the main genres of Ukrainian journalism. This genre fulfills a huge social mission: it aims to expose injustice, violations of the law, or even crimes that are ignored by law enforcement agencies.

Keywords: genre, journalistic investigations, analytical genres, analytical journalism. 


\section{Актуальність теми}

Незважаючи на те, що розслідування вважаються вищим пілотажем у професійній журналістиці, в українському науковому та інформаційному просторі до сьогодні маємо, на жаль, лише поодинокі теоретичні розробки жанрової природи журналістського розслідування та системного аналізу відповідних публікацій у друкованих 3MI (Тертычный, 2000).

Щоправда, останнім часом побачили світ кілька цікавих видань на цю тему. Зокрема, в перекладі українською вийшла книга Фолькера Лілієнталя «Розслідування» (Фолькер Лілієнталь, 2016), в якій визнаний фахівець масмедіа щедро ділиться німецьким набутком журналістських розслідувань. Особливою цінністю дослідження Ф. Лілієнталя $\epsilon$ те, що автор грунтується не тільки на власному практичному досвіді, а і на численних працях своїх колег. Саме на практиці, на конкретних прикладах показуються й аналізуються як вдалі, так i помилкові кроки журналістів-розслідувачів. Подібний досвід, безперечно, буде корисним для українських реалій.

Стан розробки проблеми

Певним прирощенням знань про специфіку побутування публіцистики розслідувального характеру в інформаційному просторі стали статті О. Дудка (Дудко, 2010), А. Бабінець (Бабінець, 2017) та інших дослідників (Василенко, 2006; Засорина,1999; Каппон, 2005; Карпенко, 2002; Кривошея, 2004).

Завданнями статті є теоретичне осмислення жанрових особливостей журналістського розслідування в інформаційному просторі.

Виклад основного матеріалу

На основі згаданих і багатьох інших публікацій можна зробити висновок про те, що журналістське розслідування - це «аналітично-публіцистичний жанр, у якому автор виявляє критично-наслідкові зв'язки, події, явища, процеси, відтворює і аргументує свою точку зору. Журналістське розслідування розглядають і як метод журналістської діяльності» (Кривошея, 2013).

Професійний вислів «журналістське розслідування» вперше побачив світ на шпальтах американської періодики наприкінці 60-х рр. $\mathrm{XX}$ ст. На думку канадського журналіста В. Маларека, в появі цього терміна неабияку роль відіграла війна у В'єтнамі, оскільки невідповідність між жорстокою реальністю і офіційними джерелами інформації була разючою.

Внаслідок численних журналістських розслідувань широкий читацький загал був об'єктивно поінформований про справжню картину військових подій, про безчинства і злочини американських вояків у В'єтнамі. Після низки публікацій на цю тему безглуздість війни стала очевидною для всіх. 
Черговою сходинкою на шляху становлення жанру журналістського розслідування була так звана «Вотергейтська справа» (від назви вашингтонського готелю «Вотергейт», у якому розмістився штаб Демократичної партії), започаткована кореспондентами газети «Тһе Washington Post» у червні 1972 р. У той час, коли всі американські друковані ЗМІ поширювали нав’язувану владою кримінальну версію пограбування штабу партії, журналісти згаданого видання почали проводити альтернативне дослідження щодо перебігу виборчої кампанії глави адміністрації Білого Дому.

Процес пошуку істини тривав два з половиною роки і завершився відставкою президента США Р. Ніксона.

Журналістське розслідування змінило хід історії і відтоді зайняло пріоритетні позиції серед найпрестижніших жанрів незалежних 3МI в Америці, а згодом і в європейських країнах. I насамперед унаслідок того, що журналісти у цих державах були захищені існуючим рівнем демократії. Варто нагадати у цьому зв'язку і сучасний процес, висвітлюваний американськими та європейськими журналістами, щодо втручання Росії у вибори президента США на користь Д. Трампа, у вибори президента Франції на користь Марі Ліпен тощо.

Україна, на відміну від США і Європи, століттями не мала власної державності, демократичних інституцій, незаангажованої преси. Саме тому жанр журналістського розслідування зароджувався в зовсім інших умовах: він виокремився в сфері художньої публіцистики I. Франка, М. Коцюбинського, М. Драгоманова, Б. Грінченка, В. Липинського, С. Єфремова, А. Ніковського, М. Хвильового та ін.

В умовах радянського тоталітаризму про оприлюднення у ЗМІ творів, які б викривали антинародний, антиукраїнський характер кремлівської влади, не могло бути й мови. Такі публікації з'являлися тільки в діаспорі. Це, зокрема, виступи В. Винниченка: «Одвертий лист до М. Горького», який полонив сучасників письменника дошкульністю й сміливістю звинувачень, кинутих в обличчя визнаному корифеєві російської радянської літератури за шовіністичну вихватку проти українського народу; «Революція в небезпеці!»; «Була, є й буде» та інші праці.

Яскравими також були публікації І. Багряного «Чад імперії», «Істерика російського фашизму», «Смітник імперії й сталінські» апельсини»», «Чому я не хочу вертатись до СРСР?», «Ціна хрущовського ведмедика», «Про свободу слова, совісті і преси за залізною заслоною» та ін., які дослідниками вважаються журналістськими розслідуваннями злочинів сталінського режиму.

На теренах підрадянської України у 60 - 70-ті pp. ХХ ст. цензура дозволяла журналістам писати лише про «окремі недоліки в будівництві комунізму». Журналістське розслідування не вписувалося в іє- 
рархію жанрів, критерії яких були чітко регламентовані ідеологами. Формально нібито дозволялося писати про все, насправді ж існували обмеження, порушувати які було ризиковано. Влада одразу реагувала.

Скажімо, журналістське розслідування Степана Колесника «Верблюд і капуста» («Радянська Україна». 1964. 16 червн.) про кричущі факти «розбазарення» державних коштів під час орошення земель, коли труби для меліорації проводилися по сухих землях заради звіту, мажорного рапорту та отримання премій, викликали різкий осуд ЦК. Журналісту оголосили сувору догану, звільнили з роботи і заборонили працювати у засобах масової інформації. Це рішення змушені були повідомити всі 3МI. За висловом М. Хрущова, преса перетворювалася на «підручних партії».

Однак навіть під загрозою репресій, психіатричних лікарень і концтаборів новітньої доби, ризикуючи не тільки своїм та своїх близьких благополуччям, а й жертвуючи власним життям, І. Світличний, I. Дзюба, В. Чорновіл, Є. Сверстюк, В. Марченко та багато інших журналістів і письменників, яких згодом назвуть «диссидентами», свою творчу енергію спрямували на боротьбу з тоталітарною системою.

У вересні-грудні 1965 р. І. Дзюба написав працю «Інтернаціоналізм чи русифікація?», яку О. Глушко назвав класичним зразком журналістського розслідування (Глушко, 2006). У своєму дослідженні не якоїсь локальної, а глобальної проблеми, хоча й старанно замаскованої пропагандистськими кліше, I. Дзюба викрив великодержавний шовінізм. Згаданому журналістському розслідуванню передував лист до тодішнього першого секретаря ЦК КПУ В. Щербицького. Відповіді не було. Тоді й з'явилося журналістське розслідування.

Через якийсь час праця І. Дзюби «Інтернаціоналізм чи русифікація?» була оприлюднена за кордоном у перекладі на російську, англійську, французьку, італійську та китайську мови. В Україні того часу вона так і не була опублікована.

Натомість з'явилася компілятивна брошура «Шо і як обстоює Дзюба?». Автора виключили зі СПУ. Не домігшись покаяння (відмови і самоосудження), його кинули до в’язниці на півтора роки.

Незважаючи на те, що з другої половини 60-х pp. ХХ ст. ідеологічна атмосфера над Україною згущується і цензура знову інтенсивно починає гальмувати друковану продукцію - ЗМІ й художню літературу (згадаймо довготривале замовчування творчості В. Симоненка, Ліни Костенко, безпрецедентне шельмування «Собору» О. Гончара тощо), письменство не спинилося в своєму розвитку. Активне покоління українських шістдесятників (І. Драч, М. Вінграновський та ін.), що виросло в умовах жорсткого ідеологічного пресингу, але не зазнало на собі тиску сталінського терору, «вважає своїм обов’язком поглиблю- 
вати процес акумуляції національної свідомості» (Кузьменко, 2018). В задушливій атмосфері передгроззя постали сприятливі обставини для «захалявного слова». На думку відомого дослідника з діаспори Юрія Бойка, сприятливість полягала у тому, що «захалявної творчости ніяка сила викорінити не в стані. Бо є люди, і $є$ читачі, що шукають справжнього, а не скаліченого насильством слова. Діють друкарські машинки, гектографи, пишуться рукою переписані копії» (Кузьменко, 2018).

Серед найрезонансніших журналістських розслідувань в умовах розбудови незалежності в Україні варто назвати публікацію Віталія Карпенка «Державний переворот» («Вечірній Київ». 1996. 8 лют.). Відомий журналіст і головний редактор газети «Вечірній Київ» чи не вперше серед представників українських масмедіа звернув увагу читачів на метаморфози в проведенні військової реформи, яку на той час активно лобіював міністр оборони Валерій Шмаров. Внаслідок проведеного розслідування Віталій Карпенко з’ясував, що замість посилення обороноздатності України, міністерство нелегітимно прагнуло ліквідувати військові округи, які залишилися після розвалу СРСР. Така «реформа» призвела б до ускладнення зв’язків із Генеральним штабом і повної втрати централізованого управління військами.

Проте найголовніше - тодішній міністр оборони пропонував розбудовувати українську армію за регіональним принципом, перевівши її на фінансування місцевими бюджетами. Інакше кажучи, за цим планом, на Донбасі та Галичині передбачалося створення територіальних армій, які б підпорядковувалася лише місцевій владі.

Одразу ж після публікації в газеті В. Шмаров звернувся до суду 3 позовом на редакцію за наклеп. Позов міністра оборони був задоволений лише частково.

Суд зобов’язав редактора «Вечірнього Києва» спростувати наведені в публікації факти і компенсувати завдану міністру оборони моральну шкоду в розмірі 315 мільйонів купонокарбованців (3150 гривень).

Натомість редакція популярного видання жодних спростувань не оприлюднювала і нічого не заплатила позивачеві. Після судового процесу, 8 липня 1996 року, В. Шмаров подав у відставку за власним бажанням.

Також не можна оминути поза увагою професійну діяльність журналіста і засновника видання «Українська правда» Георгія Гонгадзе, жертву політичного вбивства, скоєного у 2000 році. Ресурс «Української правди» він створив разом із Оленою Притулою вже наступного дня після другого Всеукраїнського референдуму, на підставі якого тодішній президент України Л. Кучма мав намір збільшити свої повноваження. У численних журналістських розслідуваннях напри- 
кінці 1999-х - на початку 2000-х рр. Г. Гонгадзе критикував діяльність Л. Кучми, розкривав його корупційні схеми власного збагачення тощо.

У липні 2000 року журналіст звернувся до Генпрокуратури України 3 проханням захистити його від невідомих осіб, які постійно стежили за ним. 16 вересня 2000 року Г. Гонгадзе зник. Журналістські розслідування Георгія Гонгадзе на тривалий час підірвали довіру значної частини українців до тодішньої влади і стали причиною багатьох антиурядових мітингів у 2000-2001 рр., відомих нині як народний рух «Україна без Кучми».

В арсеналі резонансних журналістських розслідувань - публікація, що мала назву «Перевертні» («Сьогодні». 2002. 1 серпн.), про вбивства пересічних громадян і регіональних політиків співробітниками MBC на чолі з експрацівником Управління з боротьби з організованою злочинністю підполковником Ігорем Гончаровим. Справу «перевертнів» узяв під особистий контроль тодішній президент Л. Кучма.

Лише 2005 року «справу перевертнів» передали до суду. Внаслідок судових слухань було доведено, що банда «перевертнів» Гончарова мала причетність до 13 вбивств і понад 70 злочинів. Усі члени банди в результаті були заарештовані.

Ще одне резонансне розслідування провів журналіст «Української правди» Сергій Лещенко у 2011 році. Воно стосувалося «таємниць» «Межигір'я» задовго до того, як маєток тодішнього президента України В. Януковича разом із золотим батоном - символом заможного життя олігарха став надбанням громадськості.

Після виходу розслідування всім стало зрозуміло, що скромний, порівняно $з$ цілим комплексом «Межигір'я», будиночок, який президент показав обраним журналістам у 2011 році, - не що інше, як муляж.

\section{Висновки}

За період розбудови незалежності з початку 90-х pp. XX ст. Україна пережила доволі багато політичних і суспільних скандалів, під час яких десятки чиновників були змушені з ганьбою залишити свої посади. Здебільшого першопричиною для відкриття справ ставали журналістські розслідування. Очевидно, що для деяких кіл, пов’язаних із великою політикою, бізнесом, владою, вторгнення журналістів у ці, здебільшого напівзакриті від широкої громадськості сфери, завжди було небажаним.

Однак нині, після Революції Гідності, журналістське розслідування стає одним із головних жанрів української журналістики. Цей жанр виконує величезну соціальну місію: він спрямований на викриття несправедливості, порушень закону або навіть злочинів, які залишаються поза увагою правоохоронних органів. 


\section{СПИСОК БІБЛІОГРАФІЧНИХ ПОСИЛАНЬ}

Бабінець А. «Розслідування - у тренді. Але через це знищено жанр». Журналіст України. 2017. № 1, січень. С. 12-15.

Василенко М. К. (2006). Динаміка розвитку інформаційних та аналітичних жанрів в українській пресі: монографія. Київ: Ін-т журналістики КНУ ім. Тараса Шевченка, 2006. 238 с.

Глушко О. (2006). Журналістське розслідування: історія, теорія, практика: навч. посіб. 2-ге вид. Київ : Арістей. 142 с., С. 17.

Журналистское расследование: история метода и современная практика. (2003). Под общ. ред. А. Д. Константинова. СПб.: «Издательский дом» Нева»»; Москва : ОЛМА-ПРЕСС. 480 с.

Засорина Т., Федосова Н. (1999). Профессия - журналист. Ростов-на-Дону : Феникс. 320 с.

Іванов В., Дудко О. (2010). Журналістське розслідування та журналістське дослідження в журналістикознавстві. Проблеми ідентифікації. Вісник Київського національного університету імені Тараса Шевченка. Сер. : Журналістика. Вип. 10. С. 5-12.

Каппон Р. Дж. (2005). Настанови журналістам Ассошейтед Пресс: Професійний порадник. Київ: КД «Києво-Могилянська академія». 158 с.

Карпенко В. О. (2002). Газетні жанри як комунікативні форми журналістики. Київ : КНУ імені Тараса Шевченка. 236 с.

Кривошея Г. П. (2013). Екстремальна журналістика в національному інформаційному просторі. Поняття, терміни: навч. посіб. Київ : Книжкове видавництво НАУ. 109 с., С. 59-60.

Кривошея Г. П. (2004). Журналістика: поняття, терміни. Київ : КиМУ. 202 с. Кузьменко В. (2018). У всесвіті слова: літературно-критичні студії. Київ : Друге дихання. 684 с., С. 285.

Тертычный А. А. (2006). Жанры периодической печати: учебное пособие. Москва : Аспект-Пресс, 2000. 312 с. С. 215.

Фолькер Лілієнталь. (2016). Розслідування. Пер. з нім. В.Климченко. Київ : Центр вільної преси. 135 с.

\section{REFERENCES}

Babinets A. «Rozsliduvannia - u trendi. Ale cherez tse znyshcheno zhanr». Zhurnalist Ukrainy. 2017. № 1, sichen. S. 12-15.

Vasylenko M. K. (2006). Dynamika rozvytku informatsiinykh ta analitychnykh zhanriv v ukrainskii presi: monohrafiia. Kyiv: In-t zhurnalistyky KNU im. Tarasa Shevchenka, 2006. $238 \mathrm{~s}$.

Hlushko O. (2006). Zhurnalistske rozsliduvannia: istoriia, teoriia, praktyka: navch. posib. 2-he vyd. Kyiv: Aristei. 142 s., S. 17.

Zhurnalystskoe rassledovanye: ystoryia metoda y sovremennaia praktyka. (2003). Pod obshch. red. A. D. Konstantynova. SPb.: «Yzdatelskyi dom» Neva»»; Moskva: OLMA-PRESS. $480 \mathrm{~s}$.

Zasoryna T., Fedosova N. (1999). Professyia - zhurnalyst. Rostov-na-Donu: Fenyks. 320 s. 
Ivanov V., Dudko O. (2010). Zhurnalistske rozsliduvannia ta zhurnalistske doslidzhennia v zhurnalistykoznavstvi. Problemy identyfikatsii. Visnyk Kyivskoho natsionalnoho universytetu imeni Tarasa Shevchenka. Ser.: Zhurnalistyka. Vyp. 10. S. 5-12.

Kappon R. Dzh. (2005). Nastanovy zhurnalistam Assosheited Press: Profesiinyi poradnyk. Kyiv: KD «Kyievo-Mohylianska akademiia». $158 \mathrm{~s}$.

Karpenko V. O. (2002). Hazetni zhanry yak komunikatyvni formy zhurnalistyky. Kyiv: KNU imeni Tarasa Shevchenka. 236 s.

Kryvosheia H. P. (2013). Ekstremalna zhurnalistyka v natsionalnomu informatsiinomu prostori. Poniattia, terminy: navch. posib. Kyiv: Knyzhkove vydavnytstvo NAU. 109 s., S. 59-60.

Kryvosheia H. P. (2004). Zhurnalistyka: poniattia, terminy. Kyiv: KyMU. 202 s.

Kuzmenko V. (2018). U vsesviti slova: literaturno-krytychni studii. Kyiv: Druhe dykhannia. 684 s., S. 285.

Tertысhnыі A. A. (2006). Zhanrы peryodycheskoi pechaty: uchebnoe posobye. Moskva: Aspekt-Press, 2000. 312 s. S. 215.

Folker Liliiental. (2016). Rozsliduvannia. Per. z nim. V.Klymchenko. Kyiv: Tsentr vilnoi presy. $135 \mathrm{~s}$. 